\title{
DENTAL HYGIENISTS AS ESSENTIAL MEMBERS OF THE HEALTH CARE TEAM
}

\section{LOS HIGIENISTAS DENTALES COMO MIEMBROS ESENCIALES DEL EQUIPO DE SALUD}

\author{
Juhl Jacqueline A. ${ }^{1 *}$ \\ ${ }^{1}$ RDH. BS. MS. Presiden of he Alliance of Dental Higiene Pracitioners. Estados Unidos de América. \\ *ja.juhl@comcast.net
}

\begin{abstract}
Resumen
A pesar del avance de la odontología, de los innovadores programas de salud y de los esfuerzos del personal odontológico existe una gran prevalencia de enfermedad bucal no cubierta y el gasto que esta ocasiona va en crecimiento. En el presente la oferta de servicios de salud bucal necesita ser mejorada. La incorporación de los higienistas dentales como miembros esenciales del equipo de atención primaria de la salud pueden contribuir a mejorar los resultados en términos de cobertura costo efectiva, este artículo proporciona definiciones de varios países así como de los estados Unidos de Norte América, describe sus programas educativos, sus funciones y la contribución que estos hacen en el equipo de salud.
\end{abstract}

Palabras clave: higienista dental, equipo médico, dentista, inter relaciones orales, calidad, costo-efectiva.

\begin{abstract}
Despite the advances in dental sciences, innovative oral health programs, and efforts dedicated by oral health professionals, globally, unmet oral disease, and the economic loss it causes, is growing. In the present, oral health care delivery systems urgently need improvement. The introduction of dental hygienists as essential members of the health care team can contribute to improved and cost-effective health care outcomes. This paper provides definitions of dental hygienists from both, an international and the United States (U.S.) and describes their education, functions, and contributions to the health care team.
\end{abstract}

Key words: dental hygienist, health care team, dentist, oral systemic interrelationships, quality, cost effective.

\section{INTRODUCTION}

Overwhelming global evidence indicates that, despite advances in dental sciences, innovative oral health programs, and efforts by dedicated oral health professionals, unmet oral disease and its resulting suffering and economic loss, is growing. ${ }^{1}$ Surveillance data from the World Health Organization (WHO) report trends of escalating DMFT (decayed, missing, or filled teeth [adult]), dmft (decayed, missing, or filled teeth, [deciduous teeth]), CPI (Community Periodontal Index) scores, and increasing incidences of oral cancers, cancrum oris (noma), and acute necrotizing ulcerative gingivitis (ANUG). ${ }^{1,2}$ World Bank data indicates increases in oral health care costs disproportionate compared to WHO oral health improvements reports. ${ }^{3}$ Emerging evidence establishing oral-systemic disease interactions further emphasizes the need for pro-active preventive strategies in health care delivery. ${ }^{4}$ Such ministries must strive to develop innovative evidence-based strategies to facilitate such health opportunities. Present oral health care delivery, while attempting ad- dress of this health care crisis, urgently needs improvement. The time for health care delivery system innovation is now. Those engaged in improving oral health care delivery must explore all proven options in today's environment of strained health care resources. Therefore, the purpose of this paper is to offer hope, a global vision of total health, including oral health. Such a vision can only hope to be achieved with the inclusion of the dental hygienist, the oral disease prevention specialist as an essential member of the health care team. The perspective of this opinion paper is prefaced by the author's (JJ) gratitude to the editors for the honor of inviting her to share her professional experience and research through this article. Her combined forty-four years of professional experience in public and private health includes work as a clinical and public health nutritionist, current practicing clinical dental hygienist, oral health educator and researcher from the United States (U.S.). While volunteering with the U.S. State Department-Partner Nation medical-dental teams in 2011, in the South Pacific and in Central and South America, and 
in rural communities in the southern and northwestern U.S., she has personally witnessed the needless suffering resulting from preventable oral diseases despite heroic efforts by each country's Departments or Ministries of Health and local oral health care and medical providers. Further, while an active member of both organizations, the author states unequivocally that she does not represent or speak for the American Dental Hygienists' Association (ADHA) or the International Federation of Dental Hygienists (IFDH). Opinions expressed herein are hers alone. Finally, she empathically maintains that the governments and Ministries of Health of every nation have the duty and ethical responsibility to equitably provide its citizens every opportunity for optimal health, including prioritization and promotion of oral health, within the nation's resources. Such ministries must strive to develop innovative evidence-based strategies to facilitate total health opportunities.

\section{STATE OF THE ART}

\subsection{DENTAL HYGIENISTS DEFINED}

The American Dental Hygienists' Association (ADHA) defines a dental hygienist as a licensed oral health care cotherapist whose work compliments care provided by dentists and who specializes in the ". . . recognition, prevention and treatment of oral diseases and conditions as an integral component of total health". 5 The International Federation of Dental Hygienists (IFDH) defines a dental hygienist as . . . a health professional. . ( (who has) graduated from an accredited school of dental hygiene, who, through clinical services, education, consultative planning and evaluation endeavors, seeks to prevent oral diseases, provides treatment for existing disease, and assists people in maintaining an optimum level of oral health. Dental hygienists are health professionals whose primary concern is the promotion of total health through the prevention of disease. ${ }^{6}$ Globally, the dental hygienist is a broadly educated and highly qualified oral health care provider. ${ }^{6}$

In the U.S., entry-level licensure as a dental hygienist requires fulfilment of baccalaureate or associate degree education from an American Dental Association (ADA)-accredited institution, followed by rigorous state and regional licensure testing.7 Typically, U.S. dental hygienists complete two years of general university studies in chemistry, mathematics, anatomy, physiology, psychology, and communication, and two years of didactic and clinical courses in head and neck anatomy, radiology, tooth morphology, anatomy and physiology, nutrition, cariology, periodontology, oral pathology, dental instrumentation, pharmacology, local anesthetics, dental ethics and jurisprudence, medical emergencies, cultural competency, and oral health care of special needs, pediatric, and medically compromised populations, dental restorative materials and technologies, restorative dentistry techniques including general knowledge of all dental specialties such as oral surgery, orthodontics, prosthodontics, and endodontics. ${ }^{5}$

The ADHA and the IFDH report that dental hygienists currently practice in hospitals and other health care institutions, nursing homes and senior centers, community clinics, national and regional health departments, correctional institutions, schools, higher education, and research institutions, ${ }^{6,8}$ Often, they are primary oral health care providers for society's most vulnerable, the young, the aged, the poor, the racially, ethnically or socially disenfranchised, and the developmentally disabled. ${ }^{9,10}$ Broadly educated, dental hygienists are ideally suited in varied professional roles as oral health care clinicians in private, public, or institutional clinical settings; as corporate sales representatives, educators, researchers; public health clinician and administrators; local or regional oral health program directors, program developers, and administrators; entrepreneurs in practice management companies; continuing education course developers and providers; non-profit oral health care founders and advocates; and clinical researchers in academia. ${ }^{6,8}$

\subsection{HISTORICAL CONTEXT}

The history of dental hygiene is unique among health care professions. It began in the U.S. in 1913 in the public health sector in response to the general public's lack of access to regular oral health care, particularly by children, when dental hygienist offices were then located in schools next to school nurses' offices. ${ }^{11,13}$ In 1915, dental hygienists began to be employed in hospitals and New Zealand instituted "dental nurses" in schools to provide basic oral health care on site. By 1933, U.S. dental hygienists were serving the rural poor and were based in public health clinics. As other nations learned the benefits of dental hygiene care, they began adding dental hygienists to their health care teams: Malaysia in 1949; England in 1963; Australia in 1964; Sudan in 1966; Tanzania in 1981; then others, until today when dental hygienists provide care in over 33 nations. ${ }^{9,} 12$ During the 1940's, in the U.S., dental hygiene education became more standardized and more universities began offering baccalaureate degrees in dental hygiene. In 1960, New York's Columbia University was the first to offer a Master of Science in dental hygiene, the same year dental hygienists began working with the World Health Organization to improve global oral health. ${ }^{12}$

In 1971, Washington State in the U.S. included administration of local anesthetics and placement of resin and amalgam restorations in its dental hygiene practice laws, the same year that Boston's Forsyth University began 
a study designed by the dean of the dental school. ${ }^{12,13}$ The Forsyth study demonstrated superior safety and quality by dental hygienists performing restorative dentistry functions compared to those same functions performed by dental students. Simulations of clinical private practice teams comprised of a dentist and two restorative functions dental hygienists demonstrated potential $47 \%$ annual net income increase for dentists while resulting in patient restorative fees savings of $10-25 \%$. This experiment demonstrated impressive financial and time-utilization benefits for dentists, significant cost-savings for patients, and increased professional satisfaction for dental hygienists. Unfortunately, despite public protest, the Forsyth study was terminated after the ADA denounced it disparagingly and demanded suppression of its results. ${ }^{13}$

\subsection{DENTAL HYGIENE PRACTICE VARIATIONS}

In many countries, dental hygienists practice independently from but cooperatively with dentists and other health care providers. ${ }^{6}$ Health care ministries must possess intimate knowledge of a country's cultural, spiritual, physiological, psychologic, and economic needs to develop health care systems which reflect the unique needs of its citizens. Likewise, the functions of the dental hygiene provider within a country's health care workforce must also be tailored to those needs. Countries like Canada, Israel, Australia, Nigeria, Portugal, Japan, New Zealand, and others are such examples. Dental hygienists in these countries have historically and continue to function as essential members of interprofessional health care teams while working collaboratively with dentists and a variety of health care providers. ${ }^{6}$

In the U.S.,actual dental hygiene practice laws are defined by each state. ${ }^{5}$ Johnson reported increasing collaborative and collegial interproffessional relationships as dental hygienists expand practice settings beyond private dental offices. ${ }^{11}$ In most U.S. states, supervision by a dentist of different dental hygiene functions varies. There are four different levels of supervision by a dentist depending on setting (public or private) and each state's dental hygiene laws:

1) under direct supervision, e.g. administration of nitrous oxide, means a dentist must be physically nearby;

2) under indirect supervision, e.g. the dentist authorizes the treatment and is within the facility;

3) under general supervision, e.g.: taking radiographs, the dentist may or may not be on the premises; or

4) under directaccess care.

Direct-access dental hygiene care means that a dental hygienist has the legal ability to implement the process of clinical care, that is, to assess, formulate a dental hygiene diagnosis, plan, implement, and evaluate treatment for a patient's individual needs without the specific permission of a dentist and has the legal right to sustain a providerpatient relationship with that patient. ${ }^{14}$ Provision of directaccess dental hygienist care has resulted in greater referrals to practicing dentists consistent with the ethical standards and practice laws salient to their specific practice location. ${ }^{10}$ To provide direct-access care, most states laws require that a dental hygienist has a minimum number of practice hours (e.g. 4,000 clinical hours) and a state-approved written collaborative agreement with a dentist specifying practice settings and services provided. ${ }^{15}$ Washington State began allowing direct-access care by dental hygienists to its most vulnerable populations, the aged and school children, in 1984 followed by Colorado in 1987 which legislated dental hygiene unsupervised practice in all settings. ${ }^{10,12}$ Since then, other U.S. states have amended their dental hygiene acts to allow affordable direct-access to oral health care provided by dental hygienists in 39 states with some variations of practice settings and functions including restorative and local anesthetic functions.16 Inclusion of these functions in dental hygiene state practice laws was based on high unmet population oral health care needs and maldistribution of dentists.10 Though occasionally challenged by the uninformed, the safety and quality of dental hygiene care has irrefutably and repeatedly proven itself.17 As a telling side-note, the advent of dental insurance as an employment benefit in 195418 coincided with an insidious but marked shift in dental hygiene education from public health education, promotion, and program development to more lucrative individual dental office practice. ${ }^{19}$ Almost fifty million U.S. citizens live in Dental Health Provider Shortage Areas20 in the U.S. who could greatly benefit from expanded utilization of dental hygiene preventive oral health program..$^{21}$

\section{DISCUSSION}

\subsection{Conceptual inclusion of dental hygienists in the health care team}

Evidence clearly demonstrates that dental hygienists are indeed essential members of the health care team. They save lives by providing early oral cancer screenings and referrals,23 minimizing oral pathogen colonization and preventing ventilator-associated pneumonia infections in intubated intensive care patients, ${ }^{24}$ and ameliorating the sequela of many chronic diseases. ${ }^{10}$ Figure 1 illustrates the essential of nature dental hygiene care as a health care delivery change or innovation. Harvard economist Clayton Christensen provided insight to the economics of system changes that can happen in response to innovation. ${ }^{15} \mathrm{He}$ described two kinds of system innovations that can be applied to health care delivery. The first, sustaining (or static) innovations refer to developments which support the status quo within an industry, for example, 
health care. The second, disruptive innovations are innovations which necessitate systems change because they:

1) are accessible by more people;

2) are usually more affordable, and,

3) eventually redefine and improve the system.

In some countries, implementation of dental hygiene care would require a health care system change. It is a fact that the burden of oral disease is overwhelmingly born by those who can least afford it. ${ }^{22,23}$ Da Silva applied the concepts of sustaining and disruptive innovations to oral health care delivery identifying dental sustaining innovation as highly technical treatments or instruments, and new therapeutic surgical techniques. ${ }^{27}$ While potentially producing great oral health benefits, these highly technical sustaining innovations are also expensive for both the dentist and the patient, often beyond affordability by those who bear the greatest burden of oral and systemic diseases. Conversely, global deployment of highly skilled, highly educated dental hygienists who provide cost-effective preventive, restorative, health education and promotional services, and interprofessional services, Da Silva identified as those which disrupt the status quo. These services do not necessarily require expensive ever-evolving new technologies.11 Additionally, dental hygiene care as a disruptive innovation is of great societal value because dental hygienists deliver quality oral health care at a lower cost and are accessible to more people, especially those in most need..$^{21,22}$ However, the rationale for higher oral health care cost provided by dentists compared to the same care delivered by dental hygienists in the U.S. is complex. ${ }^{28}$ An increase in corporate-owned dental practices offer new dentists some financial security but also production pressures to ensure corporate investors profits. Dental graduate education debt averages more than six times the cost of a baccalaureate dental hygiene education. ${ }^{28}$ Dental hygienists providing services in various settings have lower equipment, labor, and debt repayment expenses and are thus able to charge lower fees. ${ }^{31}$ Dental hygienists as collegial coproviders of oral health care services may initially appear to threatening to or competitive with dentists, but further scrutiny will prove to be the opposite case. Dental hygienists functioning in patientcentered health care delivery systems provide an essential referral link actually benefiting dentists, medical providers, and patients alike.

\subsection{EFFICACY OF DENTAL HYGIENE CARE}

To understand why dental hygienists are essential members of the health care team, it is essential to understand fundamental differences between the complimentary roles of dentists and dental hygienists. A dentist's primary focus is oral disease surgical treatment. Only dentists provide the most technically sophisticated treatments such as oral surgeries, complex extractions, implants, endodontics, prosthetics, and dental cosmetic treatments. It is the mastery and delivery of such procedures that contribute in part to the high cost of dental care delivery. Conversely, the dental hygienist's primary focus is oral disease prevention and abatement therapies. To maintain viable dental practices, current dental practice production strategies necessitate greater time and technologies expenditures in higher revenue-generating procedures compared to typical dental hygiene functions. For example, compare the cost of cariespreventive dental hygiene services, such as patient education, dietary counseling, or prophylactic medicament application compared to the cost of a complex surgical extraction of a non-restorable carious third maxillary molar provided by a dentist. A recent California Delta Dental Insurance analysis estimated the cost of a single molar filling over a lifetime to be $\$ 2,187$ (USD). ${ }^{32}$ The value of dental hygienists as an oral disease prevention specialist becomes obvious if considered merely in financial terms alone. ${ }^{33,34}$ In a global economy of subsidized oral health care which provides inadequate provider reimbursement, and often costly complicated administrative requirements, more cost-effective dental hygiene services are more frequently being reimbursed by insurers. ${ }^{34}$ More importantly, when a dental hygienist encounters a patient with dental or medical needs beyond the scope of practice, that dental hygienist is ethically, if not legally, bound to refer that patient to the appropriate dental or medical provider thus potentially generating greater income for that provider. ${ }^{5,35}$ In this capacity, dental hygienists are invaluable referral resources to dentists and other health care providers.

In the U.S, the 2014 National Governors Association stated that millions of Americans have limited access to basic oral health care. ${ }^{31}$ Maintenance of a viable dental practice requires population concentrations of approximately one dentist per 2,000 people resulting in a concentration of dentists in urban areas. ${ }^{36}$ Rural or remote populations are most negatively affected by this resulting maldistribution ${ }^{9}$ The loss of productivity, missed education, social implications of dental pain and tooth loss, quality of life issues, and increased risk of systemic comorbidities and death was estimated to $\$ 164$ million USD, and was associated with maldistribution of dentists in rural areas, or, a shortage of dentists in urban areas unwilling to accept patients receiving government assisted oral care.10 A study by the Minnesota Department of Health demonstrated that dental hygienists were more evenly distributed in both rural and urban areas providing needed access to oral care to populations without other dental care providers.39 Summerfelt reported successful use of tele-dentistry technologies by dental hygienists providing oral health care for remotedwelling Native American populations by working in collaboration with an urbanbased dentist. ${ }^{40}$ Interprofessional technology-enhanced collaborations between dental hygienists, dentists, and other providers could greatly improve the oral-systemic well-being 
of remote and underserved populations while ameliorating the health liabilities related to provider maldistribution.

\subsection{DENTAL HYGIENISTS IN INTERPROFESSIONAL COLLABORATIVE CARE}

Even in locations where maldistribution is not a health liability, dental hygienists are vital resources filling the cavity in present health care delivery. When working interprofessionally, like other types of specialized therapists, dental hygienists serve as oral-systemic health knowledge resources and educators to pediatricians, general medical practitioners including medical specialists such as obstetricians, internal medicine practitioners, endocrinologists, cardiologists, urologists, oncologists, orthopedic surgeons, critical care burn and wound-healing specialists, neurologists, psychiatrists and developmental disabilities specialists, and bariatric medicine specialists and general physicians, physician assistants, certified nurse practitioners, and speech, occupational, physical, and respiratory therapists. ${ }^{41,42}$ Before oral-systemic interactions were understood, only teaching hospitals associated with dental schools or dental residency programs could afford to maintain on-call dentists to serve this vital function. ${ }^{43}$ How dental hygienists can best serve in specialty practices and outpatient clinics requires knowledge of current evidence of the systemic consequences of oral diseases, especially infections of periodontal and endodontal origin.

\subsection{DENTAL HYGIENISTS' ROLE IN MEDICAL SPE- CIALTIES}

Biologic plausibility exists for many oral-systemic disease associations, but evidence-based dental hygiene practice mandates knowledge and evaluation of scientific research which is rigorously grounded in proven methodologies as the basis for patient care. Certain facts must be considered. Recent associations between chronic diseases and physiologic responses to the presences of oral pathogens have furthered understanding of inflammatory processes while underscoring the need for optimal oral health. ${ }^{45}$ The limitations of the use of oral disease surrogates in oral health research presents intrinsic challenges. $1,{ }^{44}$ In the context of this evidence, periodontal disease has been identified as a risk factor for some cardiovascular diseases and for Type II diabetes. ${ }^{54}$ Associative, rather than definitive causal relationships of varying strengths, have also been found between oral diseases and numerous systemic diseases: various cancers;52 rheumatoid arthritis $;{ }^{53}$ pulmonary infections, ${ }^{54,55}$ neurological disorders including Alzheimer disease and behavioral health; ${ }^{56-58}$ erectile dysfunction and renal disease, ${ }^{59,60}$ poor pregnancy outcomes and menopausal and post-menopausal conditions; ${ }^{61}$ obesity and bariatric surgical sequelae; ${ }^{62}$ wound and burn healing. ${ }^{63}$ Emerging research of oral microbiota and inflammatory systemic processes may result in development of better prevention strategies but, for many diseases, individualized patient education, therapeutic dental hygiene treatment and continuing care remain the gold standard.5 Many medical providers are unaware of the impact of oral infection to total health or in specific diseases, including pediatricians and emergency department physicians, ${ }^{64,65}$ To illustrate,

"Oral health care is often excluded from our thinking about health. Taken together with vision care and mental health care, it seems that problems above the neck are commonly regarded as peripheral to health care and health care policy...This separation is at odds with the fact that good oral health has been shown to directly affect a person's overall health". 66

\subsection{ROLE OF DENTAL HYGIENISTS IN INTERPROFES- SIONAL EDUCATION}

As inter-relationships of oral and systemic diseases become better understood, the need for improved interprofessional communication including dental hygienists and dentists becomes imperative. ${ }^{67}$ Medical provider education includes only a paucity of oral health content as Ferullo, Silk, and Savageau noted finding that of the 88 responding schools surveyed, only medical schools with more than 150 students offered more than five oral health curriculum hours and smaller schools offered less than five oral health curriculum hours for the entirety of the physicians' education.68 Jablonski examined seven nursing texts and found only a paucity (average of $0.6 \%$ ) of oral health education content with some erroneous or obsolete content. ${ }^{69}$ Feider, Mitchell and Bridges found that critical care nurses regarded toothbrushing ventilated patients to be arduous and difficult, and that nurses were frustrated by limited oral cavity access caused by the endotracheal tube. ${ }^{70}$ Feider, et al. concluded with Binkley, Furr, Carrico, and McCurren that critical care oral hygiene protocols were neither evidencebased nor followed. ${ }^{70,71}$ Prendergast, et. al55 demonstrated that implementation of dental-hygienists-designed evidencebased oral care protocols, recognition of abnormal tissue changes, and evidence-base, rather than traditional nursingbased, oral care products: 1) saved $65 \%$ of the oral care products institutional budget; 2) improved patient outcomes by reducing the incidence of ventilator associated pneumonia (VAP); 3) shortening critical care patient stays; and 4) proved a significant institutional and patient cost-savings. Wilder, et. al noted68 that "the mouth is a mirror" (p. 1231) but, consequently, due to a lack of education and training, nondental providers may not recognize what they are seeing "in the mirror" when they exam the oral cavity. Dental hygienists are the cost-effective resources trained to recognize potential pathologies found in the saliva, epithelial cells, oral microflora, crevicular fluid, genetic data, antibodies, drugs, and hormones of the oral cavity. ${ }^{72}$ Commitment to improved health outcomes for all 
and administrative fiscal accountability must include dental hygienists as essential members of the health care team.

\subsection{ADDRESSING BARRIERS TO INCLUDING DENTAL HYGIENISTS IN HEALTH CARE TEAMS}

Should the decision to include dental hygienist in the health care workforce or to expand existing dental hygiene practice be made, resolution of possible barriers must be addressed. Resistance from other existing professions concerned or threatened by change might reasonably be abated or resolved by educating medical and oral health providers together in pre-clinical courses. ${ }^{70}$ Opportunities for interdisciplinary peer teaching are also useful in fostering interprofessional respect and collegiality. ${ }^{73}$ The Association of American Medical Colleges suggests that interprofessional education of health care providers would foster greater understanding and respect between disciplines. ${ }^{74}$ The author (JJ) maintains that patient-centered, cost-effective, evidencebased care, including dental hygiene care, should be the unifying interprofessional focal point. Costs of national dental hygiene practice implementation, licensure, specification of education standards, accreditation policy development, and broad interprofessional and public concerns must be methodically and realistically addressed. Public education and stakeholder support are essential for the success of any change to any existing system. ${ }^{75}$ Vargas and Arevalo warned that under-utilization of dental hygienists decreased health care productivity and contributed to access to the present oral health care crisis. ${ }^{22}$

\section{CONCLUSIONS}

To countries who do not currently benefit from including dental hygienists in their current health care workforce, this author suggests exploring the data available about the significant population and health care delivery successes to be found on the International Federation of Dental Hygienists website: http://www.ifdh.org/ As dentists and dental technologies forge new technologic frontiers, dental hygienists remain uniquely qualified to promote oral health and provide cost-effective oral health care whereby they fulfill an essential role in health care teams. Imagine for a moment the quality of life benefits, increased national productivity, cessation of preventable suffering and resource wastes, and health care cost-savings a more effective health care delivery system could produce. Imagine a system in which all health care providers, including dental hygienists, synergistically focused on patient or population optimal health outcomes while celebrating each discipline's strengths and abandoning self-serving "territorial disputes". Then consider the many global examples of real oral health benefits measured in disease prevention and substantive tax-payer savings which 13 dental hygienists have brought to Portugal, Australia, Korea, and other nations. Clearly the benefits of including dental hygienists as essential members of the health care team outweigh any perceived risks and barriers. As a final thought, the author (JJ) offers the following: "We have to be willing to create change in our prevention models. . . and our understanding of what constitutes health. If we are willing to step outside the norm, we could be amazing. And . . . if not, maybe we should do something else". ${ }^{70}$

\section{Referencias}

1 Petersen PE. Challenges to improvement of oral health in the 21 st century - The approach of the WHO global oral health programme. J Pub Hlth Dent. 2004; 54:329-343.

2 Bagramian, RA, Garcia-Godoy, R, Volpe, AR. The global increase in dental caries, A pending public crisis. J Am Dent Assoc. [Internet].2009 Feb [cited 2016Feb 27];21(1) 3-8 Documento Disponible

3 World Bank [Internet]. Washington, D.C.: Health Expenditures per capita (US \$); [cited 2016 March 2].

Documento Disponible

4 4. American Dental Association [Internet]. Chicago: 2013 [cited 2016 May 12]. Action for Dental Health: Bringing Disease Prevention into Communities.

Documento Disponible

5 American Dental Hygienists' Association [Internet]. Chicago: 2008[cited 2016 May 12]. Documento Disponible

6 International Federation of Dental Hygienists. [Internet]. Washington, D.C.: 2016 [cited 2016 May12]. Facts about dental hygienists and oral health Documento Disponible

7 American Dental Association Commission on Accreditation, [Internet]. Chicago: 2012 [cited 2016 May12]. Accreditation Standards for Dental Hygiene Education Programs Documento Disponible

8 American Dental Hygienists' Association [Internet]. Chicago: no date [cited 2016 May12]. Professional roles of the dental hygienist. Documento Disponible

9 Heaton L, Smith T, Raybould T. Factors influencing use of dental services in rural and urban communities: considerations for practitioners in underserved areas. J Dent Educ [serial on the Internet]. 2004, Oct, [cited January 25, 2013]; 68(10): 1081-1089. MEDLINE. Documento Disponible

10 Naughton, D. Expanding oral care opportunities: Direct access care provided by dental hygienists in the United States, J Evid Based Dent Pract. 2014; 14S: [171-182]

11 Johnson. PM International profiles of dental hygiene 1987 to 2006: a 21-nation comparative study. Documento Disponible

12 American Dental Hygienists' Association [Internet]. Chicago: 2015 [cited 2016 May12]. Timeline. Documento Disponible

13 O'Heir, T. The Forsyth Experiment proved hygienists were good at restorative work - too good. [Internet]. Tulsa: RDH Magazine; June 13, 2016. Documento Disponible 
14 American Dental Hygienists' Association [Internet] Chica- 32 Delta Dental [Internet]. no date. [cited 2016 May24]. The go: 2016 [June 16, 2016]. Direct Access States. Documento Disponible

15 American Dental Hygienists' Association [Internet]. ChicaTrue Cost of a Cavity

33 American Dental Hygienists Association [Internet] 2015 Medicaid Reimbursement Map

go Direct Access States. 2016 [cited 2016 June 16].Docu- 34 American Dental Hygienists Association 2015 Getting mento Disponible

16 American Dental Hygienists' Association. Map of current D-A States [image on internet]. 2016 [cited June 16, 2016]. 35 American Dental Hygienists Association 2014 Bylaws CoDocumento Disponible Started- How Dental Hygienists May Achieve Reimbursement

17 Freed J, Perry DA, Kushman JE, Aspects of quality of dental 36 Smith J. [Internet]. Location, location, location: Key to hygiene care in supervised and unsupervised practices. J Public Health Dent. 1997 Spring; 57(2):68-75.

18 Delta Dental. Our History [Internet]. Seattle. Delta Dental of Washington. 2015 [cited 2016 April 18]. Documento Disponible

19 Amyot C. The Evolution of Dental Hygiene Education [Internet].Santa Ana: Dimens Dent Hyg. 2016 [cited 2016 Jun 16]

20 Oral Health [Internet]. HRSA.gov. 2016 [cited 14 June 2016].

37 Cohen L, Bonito A, Akin D, Manski R, Macek M, Cornelius L, et al. Toothache pain: a comparison of visits to physicians, emergency departments and dentists. J Am Dent Assoc [serial on the Internet]. (2008, Sep), [cited January 25, 2013]; 139(9): 1205-1216. Available at: CINAHL with Full Text

38 Minnesota Dentists Facts and Data 2008 [Internet]; Minnesota Department of Health. 2008 [cited 2016 Jun 21]; Available from:

21 Edelstein B. The dental safety net, its workforce, and policy 39 Minnesota Office of Rural Health \& Primary Care Health recommendations for its enhancement. J Public Health Dent [serial on the Internet]. 2010 Jun [cited January 25, 2013];70 Suppl 1S32-S39

22 Vargas CM, Arevalo O. How dental care can preserve and improve oral health. Dent Clin North Am 2009 Jul [cited 2016 May 12];53(3):399-420.

23 Cruz GD, Ostroff J, Kumar JV, Gandnra S. Preventing and detecting oral cancer: Oral health care providers' readiness 41 to provide health behavior counseling and oral cancer examinations. J Am Dent Assoc. 2005 May [cited 2016 June 20]; 136(5): 594-682.

24 Prendergast V, Jackson U, Renvert S, Hallberg IR. Effects of a standard versus comprehensive oral care protocol among intubated neuroscience ICU patients: Results of a randomized control trial. J Neurosci Nurs. 2012 Jun [cited 2016 April 24];44(3):134-146.

25 Durden. T., (2013) It's a "0.6\%" World: Who Owns What of The 223 Trillion In Global Wealth.

26 Christensen C. Disruptive Innovation

27 Da Silva, J. (2014) Disruptive innovation in higher education. In ADEA Signature Series: Leading Change- Disruptive innovation in higher education. Meeting conducted at the 45 Henry B. Gonzales Convention Center, San Antonio, TX.

28 American Dental Education Association [Internet]. Chicago: Educational Debt; 2015 [cited 2016 June21]. Workforce Analysis Program Profile of Minnesota Dental Hygienists [Internet]. 2005 Nov [cited 2016 Jun21].

40 Summerfelt F. Teledentistry-Assisted, Affiliated Practice for Dental Hygienists: An Innovative Oral Health Workforce Model. J Dent Ed [serial on the Internet]. (2011, June), [cited January 25, 2013]; 75(6): 733-742. Available at: Education Research Complete

41 Juhl JA. Unpublished Survey of International Dental Hygienists in Hospital-Based Practices; 2011.

42 Duley SI, Fitzpatrick, PG, Zornosa, X, Barnes WG. A center for oral health promotion: Establishing an inter-professional paradigm for dental hygiene, health care management and nursing education, J Dent Hyg [Internet] 2012 Spring [cited 2016 April 24]; 86(2):63-70

43 VanOstenberg PR, DeLaney DF, Salley JJ. Economic analysis of a dental hygienist in the hospital. J Ambul Care Manage 1983; 6:28-35.

44 Otomo-Corgel J, Pulcher, JJ, Rethman M. State of the science: Chronic periodontitis and systemic disease. J Evid Base Dent Pract. 2012 Sept [cited 2016 April 24]; 12S (S1). 20-28.

45 Lundy FT, Linden GJ. Neuroppeptides and neurogenic mechanisms in oral and periodontal inflammation. Crit Rev Oral Biol Med [Internet]. 2015 [cited 2016 April 24];15(2):82-98

29 American Dental Education Association [Internet]. Chica- 46 Katz, J, Wallet, S, \& Seunghee, C. Periodontal disease and go: Program costs; 2015 [cited 2016June 21].

30 Saleirno C.[Internet]. Is Student debt influencing new dentists' Choices after graduation? Dent Econ; [Place Unknown]: 2016[cited 2016 June 21]

31 United States of America. The role of the dental hygienist in providing access to oral health care. Washington, D.C.; National Governors Association. 2014 [cited 2016 June 21] the oral-systemic connection: İs it all the RAGE?" Quintessence Inter, [Internet]. 2010 [cited 2016 Jun21];41(3): 229237.

47 Chavakis T1, Bierhaus A, Nawroth PP. 2004 Nov RAGE (receptor for advanced glycation end products): a central player in the inflammatory response. Microbes Infect. [Internet]. 2004 [cited 2016 Jun 21]; 6(13):1219-25. 
48 Wu T, Trevisan M, Genco, RJ, Dorn JP, Falkner KL, Sempos CT. Periodontal disease and risk of cerebrovascular disease, 64 the first national health and nutrition examination survey and its follow-up survey. Arch Intern Med [Internet]. 2000 [cited 2016 Jun 3];160(18):2747-2755.

49 Kelly JT, Avila-Ortiz G, Allareddy V, Johnson GK, Elangovan $\mathrm{S}$. The association between periodontitis and coronary 65 heart disease. J Am Dent Assoc. 2013 April; 144(4) 371379.

50 Mealey BL. Periodontal disease and diabetes, a two-way street. J Am Dent Assoc [Internet] 2006 Oct [cited 201666 April 25];137: 26S-31S. Lamster IB, Lalla E, Borgnakke WS. The relationship between oral health and diabetes mellitus. J Am Dent Assoc. 2008 Oct; 139:19S-24S

51 Tsai H, Hayes C, Taylor GW. Glycemic control of type 2 diabetes and severe periodontal disease in the US adult population. Community Dent Oral Epidemiol [Internet]. 68 2002 Jun [cited 2016 June 21]; 30:182-192.

52 Missih, C. The link between periodontal disease and cancer: A review. Perio-Implant Advisory; 2016 [cited 2016Jun].

53 Treister N, Glick M. Rheumatoid arthritis: A review and 69 suggested dental care considerations. J Am Dent Assoc. 1999 May; 130:689-697.

54 Paju S, Scannapieco FA. Oral biofilms, periodontitis, and 70 pulmonary infections. Oral Dis. [Internet] 2007 Nov [cited 2016 April 11];13(6):508-512.

55 Prendergast V, Kleinman C, King M. The bedside oral exam and the barrow oral care protocol: Translating evidenceba- 7 sed oral care into Pract Intens and Critic Care Nurs. 2013 29, 282-290.

56 Freidlander AH, Friedlander IK, Marder SR. Bipolar 172 disorder, psychopathology, medical management and dental implications. J Am Dent Assoc. 2002 Sept; 133:1209-1217.

57 Watts A, Crimmins EM, Gatz M. Inflammation as a potential mediator for the association between periodontal disease and Alzheimer's disease. Neuropsychiatr Dis Treat 73 [Internet] 2008 [cited 2016 June 21] 2008:4(5) 865-876.

58 Stein PS, Desrosiers M, Donegan SJ, Yepes JF, Kryscio RJ. Tooth loss, dementia and neuropathology in the Nun Study. 74 J Am Dent Assoc. 2007 Oct; 138:1314-1322.

59 Zadik Y, Bechor R, Galor S, Justo D, Heruti RJ. Erectile dysfunction might be associated with chronic periodontal disease: Two ends of the cardiovascular spectrum. J Sex 75 Med [Internet] 2009 [cited 2016 April 26]; 6:1111-1116.

60 De Rossi SS, Glick M. Dental considerations for the patient with renal disease receiving hemodialysis. J Am Dent As- 76 soc. $1996 \mathrm{Feb} ; 127(2): 211-219$.

61 Krejci C B, Bissada, NF, Women's health issues and their relationship to periodontitis. J Am Dent Assoc. 2002 March 133(3):323-9

62 Hague AL, Baechle M. Advanced caries in a patient with a history of bariatric surgery. J Dent Hyg [Internet] 2008 April [cited 2016 April 24]; 82(2)86(2):1-9.

63 Guo S, DiPietro LA. Factors affecting wound healing J Dent
Research. 2010Mar; 89(3):219-229.

4 Trivedy C, Kodate N, Ross A, Al-Rawi H, Jaiganesh T, Harris T, Anderson JE. The attitudes and awareness of emergency department (ED) physicians towards the management of common dentofacial emergencies. Dent Traumatol [Internet] 2012 [cited 2016 Feb 15]; 28.121-126.

5 Lewis CW, Boulter S, Keels MA, Krol DM, Mouradian WE, O'Connor KG, Quinonez RB. Oral health and pediatricians: Results of a national survey. Acad Pediatr. 2009 NovemberDecember; 9(6):457-461.

66 IOM (Institute of Medicine). Advancing Oral Health in America. [Internet]. [Washington, D.C.]: The National Academies Press. 2010; [cited 2016 May 24]

67 Wilder RS, O'Donnell JA, Barry M. Galli, DM, Hakim, FF, Holyfield, LJ, Robbins, MR. J Dent Educ [Internet]. 2008 Nov [cited 2016 June 21];. 72 (11): 1231-1237.

68 Ferullo A, Silk H, Savaugeau JA. Teaching oral health in U.S. Medical Schools: Results of a national survey. Acad Med [Internet]. 2011 Feb [cited 2016 April 12];862):226230.

69 Jablonski RA. Oral health and hygiene content in nursing fundamentals textbooks. Nurs Res Pract 2012 [cited 2016 May 24]; 2:372617.

0 Feider LL, Mitchell P, Bridges E. Oral Care Practices for Orally Intubated Critically Ill Adults Survey of oral care practices in US intensive care units. Am J Infect Control. 2004 [cited 2016 May 24]; 32(3):161-169.

1 Binkley C, Furr LA, Carrico R, McCurren C. Survey of oral care practices in U.S. intensive care units. Am J Infect Control. 2004 May; 32(3):161-169.

72 Forsyth JM in Da Silva J. Disruptive innovation in higher education. In ADEA Signature Series: Leading ChangeDisruptive innovation in higher education.2014. Meeting conducted at the Henry B. Gonzales Convention Center, San Antonio, TX.

73 Mabry CC, Mosca NG. Interprofessional education partnerships in school health of children with special oral health needs. J Dent Educ Aug; 2006; 70(8):844-850.

74 Association of American Medical Colleges [Internet]. Washington, D.C.: Report IX Contemporary issues in medicine: Oral health education for medical and dental students. 2008 Jun [cited 2016 Jun]

5 De Branbandere L, Iny A. A New Paradigm for Business Creativity, Thinking in New Boxes. New York, NY: Random House. 2013.

76 Gurenlian JM. Can we change the world? [Internet]. Tulsa:RDH Magazine Online;2011[cited 2016 Feb 12]

Recibido: 25 de Marzo de 2016

Aceptado: 20 de Abril de 2016 